\title{
39. PROVENANCE OF THE JURASSIC-CRETACEOUS FLYSCH, DEEP SEA DRILLING PROJECT SITES 370 AND 416
}

\author{
Ilfryn Price, ${ }^{1}$ The British Petroleum Co. Ltd., Britannic House, Moor Lane, London, EC2Y 9BU, United Kingdom
}

\section{INTRODUCTION}

Drilling at DSDP Sites 370 and 416 (Figure 1) has revealed an apparently uninterrupted "flysch" sequence of Tithonian to Aptian distal turbidites (Figure 2). Comparable sequences of similar age outcrop in the RifBetic Mountains (Michard, 1976; Wezel, personal communication). This paper examines the provenance of the Sites 370 and 416 succession, with particular emphasis on the lower part of the sequence, that which was continuously cored in Hole 416A, and described on a bedby-bed basis (Site 416 report, this volume).

\section{THE SITES 370 AND 416 SEQUENCE}

Figure 2 is a composite log of DSDP Holes 370 and 416A. Units V, VI, and VII (Site 416 report, this volume) are subdivisions of a continuous sequence of cyclic, thinly to very thinly bedded sandstones, siltstones, mudstones, and (in Unit VII) micritic limestones. Graded bedding, erosional bottom structures, and Bouma sequences indicate that the majority of the cyclic beds are turbidites, although some intervals with coarser sediments and sharp upper contacts probably record reworking by bottom currents.

Detailed descriptions of the sequence are presented in the Site 416 report in this volume. The sequence is summarized in Table 1.

Only the lower part of Unit VI and Unit VII have been continuously cored and described on a bed-by-bed basis. Figure 3 illustrates the vertical variation of four common indexes of proximity over this interval. Average bed thickness is the most sensitive index and shows a pronounced minimum value in the lower part of Unit VI (Cores 416A-31 through 36). The overlying section shows a gross upward thickening, suggesting a prograding sequence (e.g., Ricci-Lucchi, 1975). Above 1185 meters the details of the variation of the flysch are less well known, but the scarcity of sand and silt layers in Unit V relative to Unit VI suggests a gradual decline in clastic flux to the basin during post-Hauterivian times.

\section{Composition}

Some 150 thin sections and stained acetate peels of sandstone and siltstone from Hole 416A were examined to determine the composition of the detrital fraction.

\footnotetext{
1 Present address: BP Petroleum Development Co. Ltd., Farburn Industrial Estate, Dyce, Aberdeen, United Kingdom.
}

Visual estimates of the ratio of siliceous and calcareous material are shown on Figure 4. Individual components were estimated as dominant ( $>70 \%$ of the total detrital fraction), common $(25 \%-70 \%)$, present $(5 \%-25 \%)$, trace $(1 \%-5 \%)$, or rare $(<1 \%)$. Simplified results are shown on Figure 5.

Routine petrographic descriptions were supplemented by X-ray-diffraction analysis of clay minerals and heavy-mineral determinations on selected samples. The relative abundance of siliceous and calcareous detritus (Figure 4) shows that one or other component constitutes more than 90 per cent of most of the individual turbidites. A quartzose admixture in a predominantly calcareous arenite is more common than the reverse situation. This trend may be re-enforced by the tendency for calcareous material to be concentrated preferentially within the lower part of any one graded bed. Assuming that individual turbidites have a lateral, as well as a vertical, decrease in grain size, many of those samples could have been so "distal" that any calcareous detritus entrained in the original turbidity current was deposited before reaching Site 416 .

This explanation cannot, however, apply to the disappearance of calcareous detritus above Core 416A-25 (Figure 4), as the thicker beds (Figure 3 ) indicate a prograding sequence in that part of the section. Moreover, the disappearance of calcareous detritus corresponds to a distinct break in bed thickness, fauna (Sliter, this volume), and type of organic matter present in the section (Galimov; Boutefeu; both this volume), suggesting that all these elements are tied to the history of turbiditycurrent activity at the site. No coarse layers with more than 90 per cent carbonate debris were found in Unit VI, whereas they predominate in Unit VII except for a zone of quartzose sediments between Cores 416A-46 and 54. A less marked quartzose zone is also present in Cores 416A-36, 37, and 38 (Figure 4). In each case there is some suggestion of a gradual upward decrease in calcareous material, as is the case at the base of Unit VI.

The sequence above 1185 meters at Site 370 (Lancelot, Seibold et al., 1978) was not logged in as much detail as that below. Abundant shallow-water calcareous debris re-appears in Core 370-45 (1062.5-1072 m: Hauterivian) and disappears in Core 370-32 (834.5-844 m: lower Aptian; data from L. F. Jansa, personal communication).

Analysis of individual components indicates that quartz predominates (Figure 5). Relict oxide and quartz rims on several quartz grains indicate a pre-existing sedimentary source for at least part of the quartz fraction. 


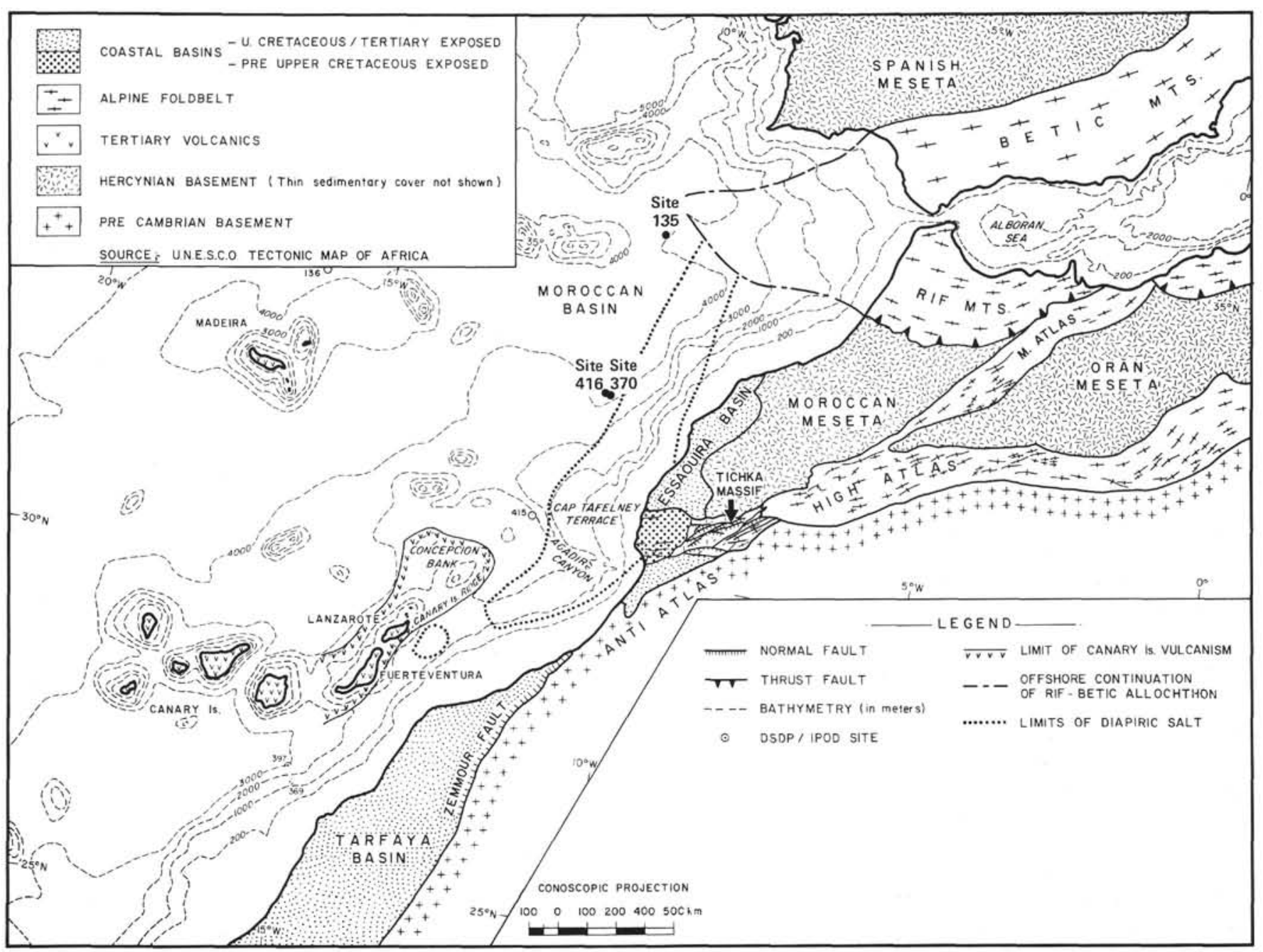

Figure 1. Tectonic map of the Moroccan continental margin, showing localities mentioned in the text.

Plagioclase and K-feldspar, including microcline, occur in roughly equal amounts, but both are relatively rare in the lower part of Unit VI and the upper part of Unit VII. Biotite and muscovite are both ubiquitous. Zircon is the most common heavy mineral and occurs with rutile, tourmaline, and a few garnets, which are especially numerous in Unit VI. Pyrite is the dominant opaque mineral in the upper part of Unit VI, whereas magnetite is more common below Core 416A-14. Chert and quartzmica schist dominate the lithic fraction, with occasional quartzose arenites and felsitic volcanic rocks.

Micritic lumps and pellets dominate the calcareous detrital fraction. Calpionellid micrites below Core 416A35 suggest a pelagic source for much of the detrital micrite, perhaps the adjacent continental slope. In Core $416 \mathrm{~A}-7$, on the other hand, a clast of calpionellid limestone presumably represents erosion of older slope sediments. Neritic detritus is less common, but coated grains and faunal remains indicate that some debris must have originated on a carbonate shelf (see Schlager, this volume, for a more detailed díscussion).

\section{DISCUSSION}

The source area of the Site 416 flysch was a region of diverse geology. The various turbidites in Unit VII indicate that two separate provinces contributed material to the outer continental margin. One was a calcareous shelf and slope, the other a terrain of mainly older sedimentary rocks with some exposed schists and, judging by the presence of microcline, granitoid or gneissic basement. The bed-thickness data can be most simply interpreted as indicating that the calcareous source area was slightly closer to Site 416 than the terrigenous province.

The history of transgressions and regressions in the Essaouira basin, east of Site 416 (Société Chérifiene des Pétroles, 1966) is shown on Figure 4. Regressive episodes onshore are clearly matched by a relative pulse of siliciclastic deposition in deep water, whereas the interval of thinnest beds in the Valanginian (Figure 3) corresponds to the apex of a short-lived transgression.

The non-calcareous fraction could have been derived from the hinterland of the Essaouira basin. On the 
SITES 416 and 370 (Lat. 3250.2 'N; Long. 1048.1 W)

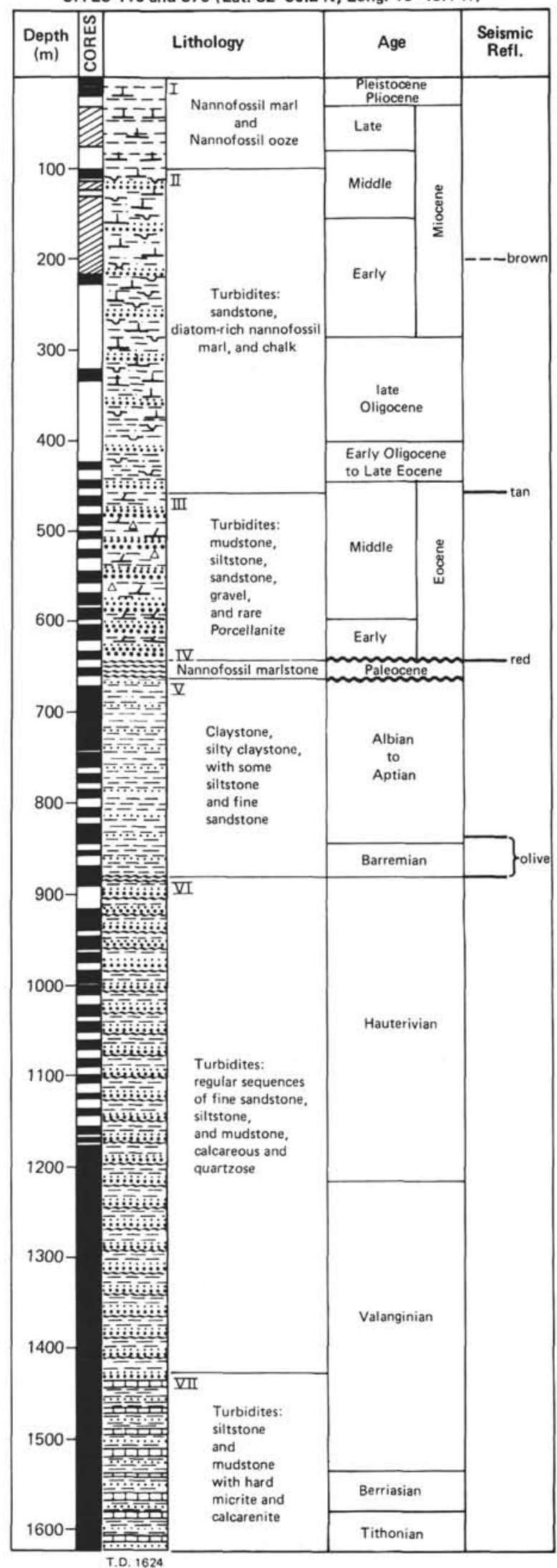

Figure 2. Summarized stratigraphic column for DSDP Sites 370 and 416.
TABLE 1

Summary of Lithologic Sequence, Sites 370 and 416

\begin{tabular}{|c|c|c|c|}
\hline Unit & Depth (m) & Stratigraphy & Description \\
\hline V & 661 to about 880 & $\begin{array}{l}\text { L.-M. Eocene to } \\
\text { L. Aptian }\end{array}$ & $\begin{array}{l}\text { Blue-green to olive-black mud- } \\
\text { stone with thin laminae of } \\
\text { quartz siltstone, rare calcare- } \\
\text { ous sandstones, and pebbly } \\
\text { mudstones }\end{array}$ \\
\hline VI & About $880-1430$ & $\begin{array}{l}\text { L. Aptian to } \\
\text { Valanginian }\end{array}$ & $\begin{array}{l}\text { Cycles of brown or gray-green } \\
\text { sandstone and siltstone grading } \\
\text { to mudstone and calcareous } \\
\text { mudstone; detrital layers more } \\
\text { abundant than in Unit V }\end{array}$ \\
\hline VII & $1430-1628$ & $\begin{array}{l}\text { Valanginian to } \\
\text { Tithonian }\end{array}$ & $\begin{array}{l}\text { Cycles of interbedded brown } \\
\text { quartz sandstone and siltstone } \\
\text { grading to mudstone, red zeo- } \\
\text { litic mudstone, and calcarenite } \\
\text { and micritic siltstone grading } \\
\text { to gray marlstone or pinkish } \\
\text { gray micrite }\end{array}$ \\
\hline
\end{tabular}

Moroccan Meseta (Figure 1) metamorphic basement is partially covered by locally derived upper Paleozoic and Triassic clastic sedimentary strata (Michard, 1976). The metamorphic core of the Atlas Mountains, exposed in the Tichka Massif (Figure 1), is flanked by Triassic continental red beds (Gar, 1974; Van Houten, 1977)-a situation which would offer an ideal source for the Site 416 succession. The control exerted by sea-level changes in the Essaouira basin over the Site 416 flysch supports the idea that the hinterland of that basin was the source for the flysch. Isopach data from the Essaouira basin (Société Cheriffienne des Pétroles, 1966) indicate that the western Atlas was a relative high in latest Jurassic and Early Cretaceous times. Terrigenous detritus off this high might have been funneled into the flanking trough to the north (Figure 6), bypassing the main Moroccan shelf.

There are, however, alternative (Figure 6) interpretations. All or part of the Site $\mathbf{4 1 6}$ sequence could have arrived by essentially axial transport from a source in either the Rif-Betic system to the northeast, or the Tarfaya basin and Anti-Atlas to the south (Figure 1). The Rif-Betic area was, in latest Jurassic and Early Cretaceous times, the site of deposition of a flysch sequence very similar to that at Site 416 (Wezel, personal communication). However, rather than to explain the latter as derived from the former, it seems more plausible to invoke a common source in the Moroccan Meseta and the High Atlas (Figure 6).

The Tarfaya basin was a Jurassic carbonate province which was swamped during the Early Cretaceous by continental-deltaic clastic deposits (Martinis and Visintin, 1966). Robertson and Stillman (in press) recently discovered a probably deep-water equivalent of this clastic sequence beneath the igneous complex on the island of Fuerteventura (Figure 6). The bathymetric barrier of the Canary Islands ridge and Cap Tafelney terrace which now separates Site 416 from the southern Moroccan continental slope (Figure 1) was probably non-existent in early Cretaceous time (Price, this volume) and turbidity currents from the Tarfaya slope could conceivably have reached Site 416 . Sands from 


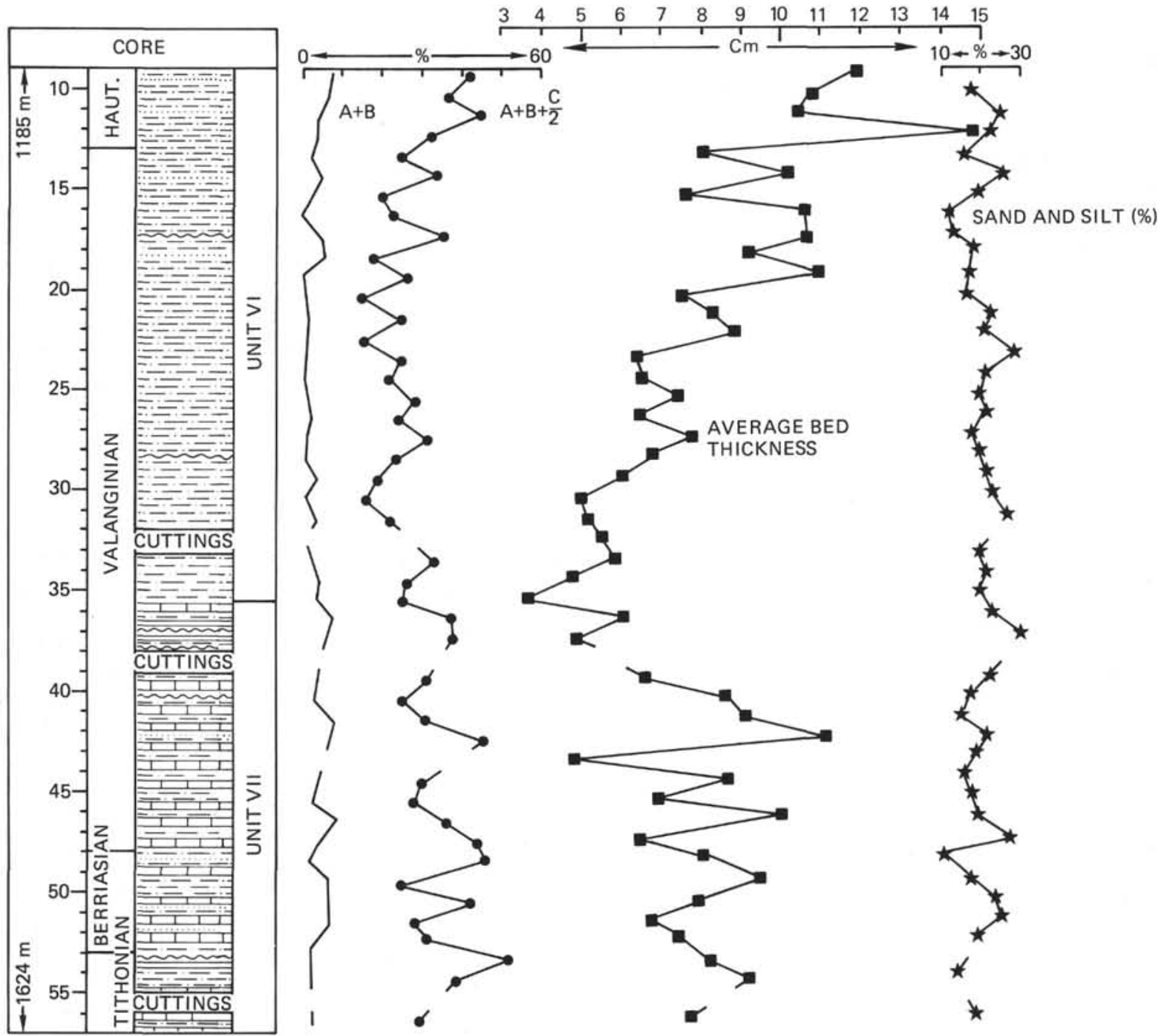

Figure 3. Vertical variation in indexes of Cores 416A-10 to 416A-57. Each value is an average per core. $A+B=$ percentage of beds starting with Bouma $A$ or $B$ intervals. $C / 2=$ half percentage of beds starting with Bouma $C$.

the two sequences show a similar range of siliceous detrital material to that of sediments in Hole 416A, but the presence of perthitic feldspars and plutonic lithic fragments and a relative lack of mica and lithic schist and arenite grains indicates a greater plutonic contribution to the Fuerteventura succession. Moreover, calcareous debris is restricted to the very base of the Fuerteventura section (Robertson, personal communication). The two sequences, while similar, are not therefore identical, and although a southern source for the Site 416 flysch cannot be ruled out, a source to the east seems more tenable.

\section{ACKNOWLEDGMENTS}

I am grateful to Professor F. O. Wezel for details of the flysch succession in the Rif-Betic system and to Dr. A. H. F. Robertson who provided information on, and samples from, the Mesozoic sediments on Fuerteventura. Drs. V. N. D. Caston, W. Schlager, and L. F. Jansa provided helpful comments on earlier drafts of the manuscript.

\section{REFERENCES}

Ager, D. V., 1974. The western High Atlas of morocco and their significance in the history of the North Atlantic, Geol. Assoc. Proc., v. 85 , p. 23-41.

Martinis, B. and Visintin, V., 1966. Données géologiques sur le bassin sedimentaire cotier de Tarfaya (Maroc Meridional). In Reyre, D. (Ed.) Bassins sedimentaires du Littoral Afraicain. Assoc. Serv. Geol. Africain Publ., p. 13-26.

Michard, A., 1977. Elements de Géologie Marocaine, Notes Mem. Serv. Geol. Maroc., No. 252.

Lancelot, Y. Siebold, E., et al., 1978. Site 370: Deep basin of Morocco. In Lancelot, Y., Siebold, E., et al., Initial $R e$ ports of the Deep Sea Drilling Project, v. 41: Washington (U.S. Government Printing Office), p. 421-492.

Ricci-Lucchi, L., 1975. Depositional cycles in two turbidite formations of Northern Appenines (Italy), J. Sediment. Petrol., v. 45 , p. 3-43.

Robertson, A. H. F. and Stillman, C. J., in press. The sedimentary rocks of Fuerteventura, Canary Islands, and the 

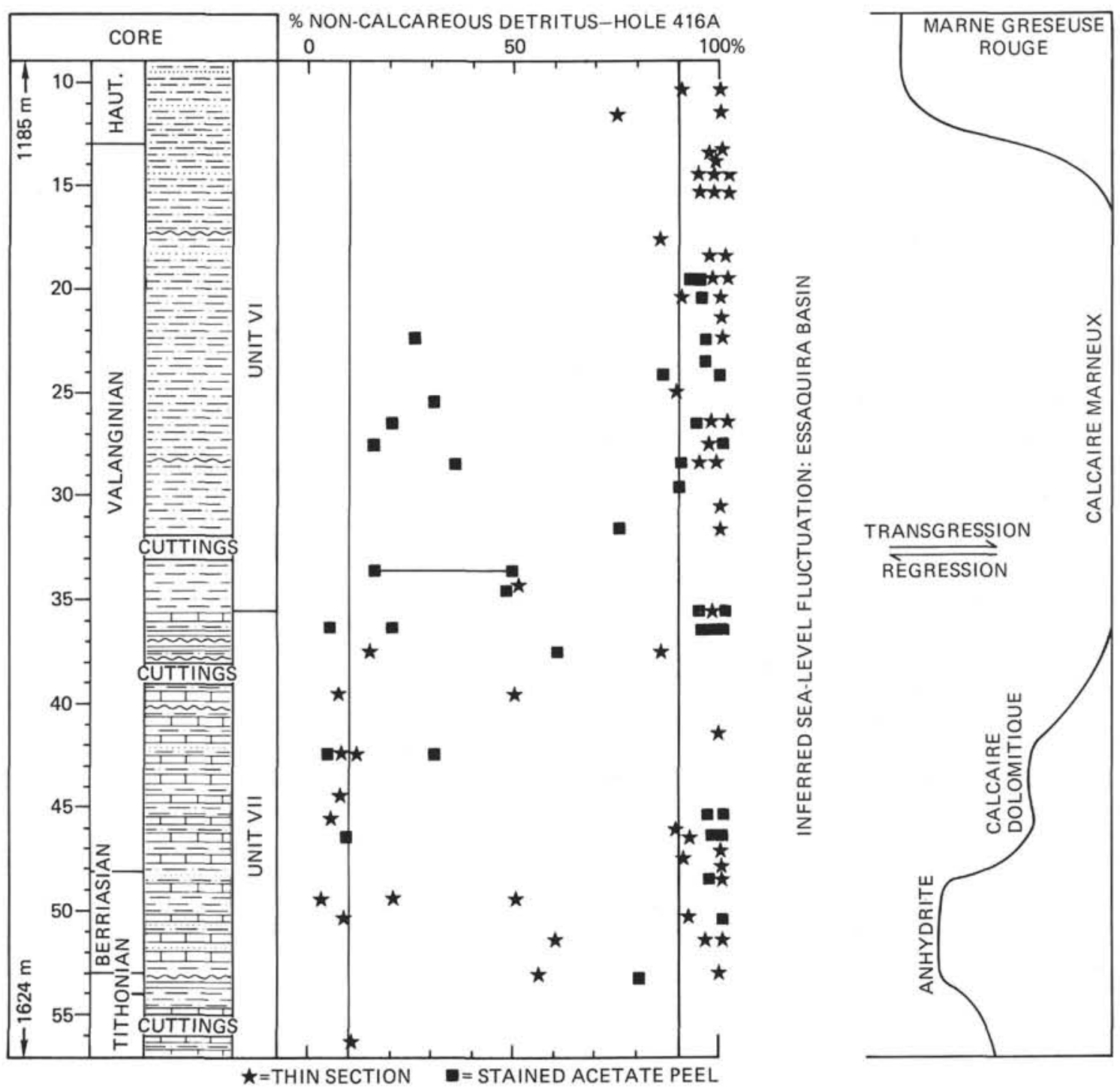

Figure 4. Composition of individual coarser intervals in Cores $416 A-10$ to $416 A-57$ compared with the relative sea-level changes in the onshore Essaouira basin. The onshore facies for each time interval are taken from SCP (1966).

evolution of the West African continental margin, J. Geol. Soc. London.

Société Chérifienne des Pétroles, (SCP) 1966. Le bassin du Sud-Ouest Marocain. In Reyre, D. (Ed.) Bassins sedimen- taires du Littoral Africain. Assoc. Serv. Geol. Africain Publ., p. 5-12.

Van Houten, F. R., 1977. Triassic-Liassic deposits of Morocco and eastern North America: comparison, Am. Assoc. Petrol. Geol. Bull., v. 61, p. 76-99. 

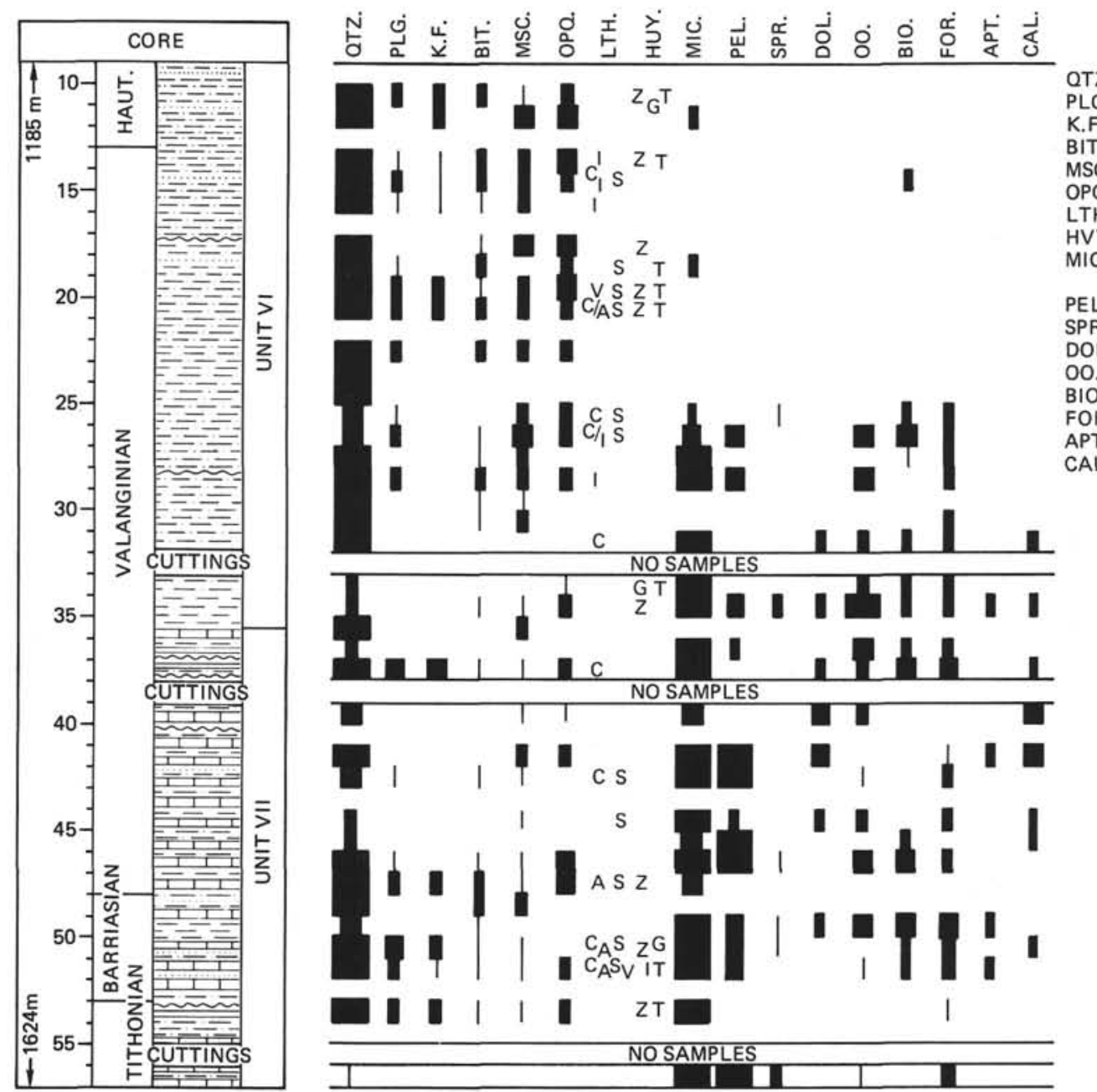

QTZ QUARTZ

PLG. PLAGIOCLASE

K.F. K-FELDSPAR (INC. MICROCLINE)

BIOTITE

MUSCOVITE

OPQ. OPAQUE MINERALS

LTH. LITHIC FRAGMENTS

HVY. HEAVY MINERALS

MIC. MICRITE (LUMPS, INTRACLASTS,

PEL. PELOIDS

SPR. DETRITAL SPARITE

DOL. DETRITAL DOLOMITE

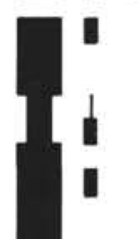

-

OOIDS

BIO. NERITIC BIOGENIC MATERIAL

FOR, FORAMINIFERS

APT. APTYCHI

CAL. CALPIONELLID LIMESTONE

HEAVY MINERALS

$Z=Z I R C O N$

$T=$ TOURMALINE

$\mathrm{G}=$ GARNET

LITHIC FRAGMENTS

I = INTRAFORMATIONAL MUD

$\mathrm{C}=$ CHERT

$A=$ ARENITE

$\mathrm{S}=\mathrm{SCHIST}$

$V=$ VOLCANIC

ABUNDANCE SCALE
$>25 \%$
$5-25 \%$
$1-5 \%$
$<1 \%$

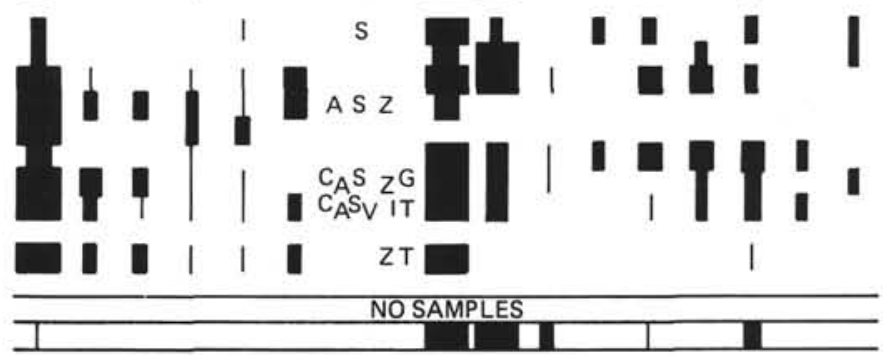

Figure 5. Composition of sand layers, Cores 416A-10 to 416A-57. The abundances shown are the largest measured in any sample from a given core; hence, for some cores, the chart is a composite of more than one sample. 


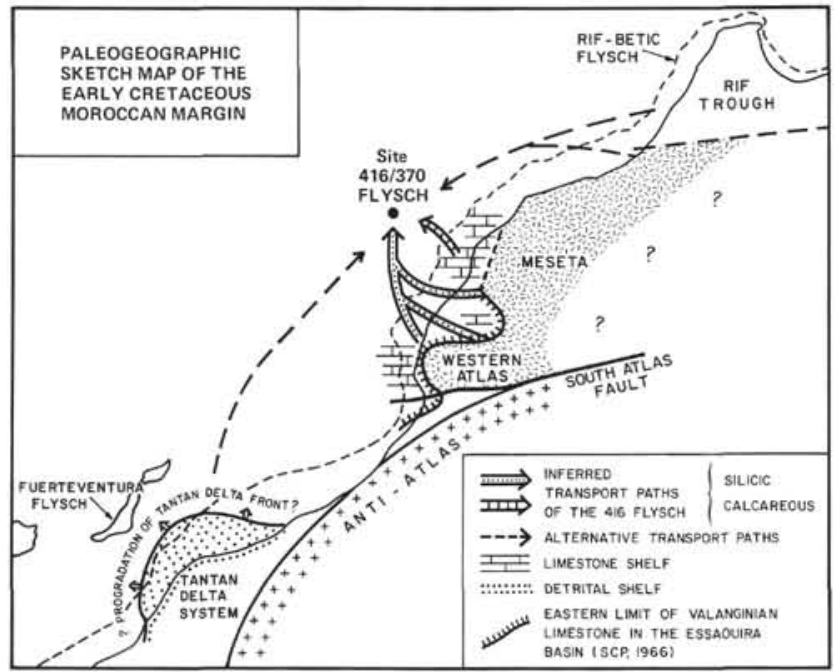

Figure 6. Map showing the inferred derivation of the Sites 416 and 370 flysch and its position in relation to similar and probably coeval sequences. Symbols indicating basement type are the same as those used in Figure 1. The map is drawn with the present-day coastline and 200-meters isobath as a base. No attempt has been made to allow for possible Late Cretaceous sinistral movement along the South Atlas fault (cf., Price, this volume). The outline of the Tantan Delta is entirely schematic. 